\title{
Capacity Strengthening of Extension Institutional in District Level for Farmer Regeneration in Sukabumi Regency
}

\author{
Wida Pradiana; Ait Maryani \\ Department of Agriculture, Bogor Agricultural Development Polytechnic, Indonesia
}

http://dx.doi.org/10.18415/ijmmu.v6i5.1084

\begin{abstract}
Farmer regeneration has been accelerated through strengthening the institutional capacity of agricultural extension. The research aims to analyze the dynamics of district-level extension institutions as an activity node to attract young farmers, analyze the factors that influence the capacity of district-level extension institutions in supporting farmers 'regeneration programs and formulate district-level extension institutions in supporting farmers' regeneration programs. The study was conducted in Sukabumi Regency, West Java Province. A population of 115 people were taken as respondents. Research variables include institutional characteristics of farmers (X1), institutional support (X2), institutional capacity (Y1) and behavior of young farmers (Y2). This research variable was developed into a research instrument in the form of a questionnaire. The research instrument has passed the stages of validity and reliability with valid and reliable results. Data analysis uses descriptive statistical and path analysis. The results obtained by all aspects that characterize the counseling institution are in the medium category. The institutional characteristics of extension, simultaneous support of extension institutions have a direct influence on institutional capacity of extension and also have a direct influence on changes in behavior of young farmers. The strategies that can be formulated to change the behavior of young farmers are to strengthen the characteristics of extension institutions that are integrated with technical institutions, increase institutional management support through the provision of extension infrastructure and develop operational standard procedures, and create programs that provide added value to young farmers.
\end{abstract}

Keywords: Regeneration of Farmers; Young Farmers; Agricultural Extension Institutions

\section{Introduction}

Currently, the role of extension institutions to support the farmers' regeneration program has not achieved its expected results. Wardani and Anwarudin (2018) reported that the role of extension agents and farmer institutions was not optimal in its function in supporting farmers' regeneration. This situation is exacerbated by the different institutional conditions in each regency due to the existence of Regulation Number 23 of 2014 concerning local governments which regulates extension institutions. Koentjaraningrat (1997) asserts that an institutional is a system which place its pattern in humans and a norm system that embodies a culture. Institutional have cultural and structural aspects which consist of 
norms, values and social roles (Tony and Utomo, 2004). Due to the fact that extension institutional is a national culture that has already rooted in Indonesian society, thus it will be ironic if the institutions disappear because of changes in the existing order. The decline of ability of extension institutions can be felt by the reduction of competent extension agents due to the appointment moratorium problem and issues related to extension agent workforce as well as the decrease of young men and women who want to work in the agricultural sector.

The results of the 2013 Agricultural Census (BPS 2014) showed the portion of agricultural business households by age group of farmers, namely aged over 54, 35-54 and less than 35 years were $32.76 \%, 54.37 \%$, and $12.87 \%$, respectively. Comparing the BPS data for 2003 with 2013, it can be seen that in the past 10 years there has been a decline of almost $15 \%$ of farm households engaged in agriculture. The data indicates that the majority of farmers in Indonesia are elderly and proves that there is a decline of population who are engaged in agriculture field, especially among the younger generation. The decrease in number of farmer households can be due to the workforce shifted to other sectors was in greater number than the new workforce in the agricultural sector. In addition, the low interest of farmers to join any farmer groups result in a weak bargaining position of the farmers.

Encountering such conditions, educational institutions must be developed and strengthen in an effort to assist the main actors in creating a conducive educational/ learning climate, hence they will be capable to support themselves in improving their family welfare. The role of agricultural extension agents is to assist farmers form healthy opinions and make good decisions by communicating and providing information needed by farmers. Moreover, agricultural extension agents also play a role in assisting farmers in improving their farming (Van den Ban and Hawkins 1999).

Extension agents are the frontline who can make direct contact with farmers. Their position as the frontline describes how agricultural extension agents have various abilities that can be used to support them in doing their duties and functions in order to empower the farmers. The problems faced by agricultural extension agents is not only related to farming issues, but also cultural, social, knowledge and trust levels of the farming community. Therefore agricultural agents are required to use various approaches to assist farmers to solve problems. Based on the explanation aboves, the study aims to analyze the dynamics of subdistrict level extension institutions as a node of activity to attract young $\mathrm{g}$ agricultural actors, analyze the factors that influence the capacity of subdistrict level extension institutions in assisting agricultural regeneration programs and formulate subdistrict level extension institutional strategies in supporting agricultural regeneration programs.

\section{Research Method}

This research was conducted from May to September 2017 in Sukabumi Regency, West Java Province. The research site was selected based on the the existence of young generation of farmers which has been empowered through extension activities by Food Crops, Horticulture and Plantations Service. The population used in this study consisted of young farmers who were members of Farmer Groups and Gapoktan in subdistrict level with total respondent of 115 person according to Distanhorbun, Sukabumi Regency.

Data consists of primary data and secondary data. The main source for the primary data was the young farmers who were interviewed using questionnaires and was guided directly by researchers. Secondary data source was second and third parties in the form of research results, records, documents, and written reports. Secondary data were collected through literature study. The research instrument used in the collection of primary data consisted of a questionnaire (contained a list of closed and open 
questions) for structured interviews, guidance for in-depth interviews and focus group discussions. Logbook was used to record the data or process documentation.

The research variables consisted of independent and dependent variables. The independent variables included farmer institutional characteristics $\left(\mathrm{X}_{1}\right)$ and institutional support $\left(\mathrm{X}_{2}\right)$. The dependent variables were institutional capacity $\left(\mathrm{Y}_{1}\right)$ and behavior of young farmers $\left(\mathrm{Y}_{2}\right)$. The research variable was developed into a research instrument in the form of a questionnaire. The research instrument had passed the stages of validity and reliability with valid and reliable results.

Data analysis used two types of analysis, namely quantitative analysis and qualitative analysis. Quantitative analysis was done by using path analysis, while qualitative analysis used as a quantitative complement was descriptive approach and system thinking. For the purposes of the data analysis, the ordinal primary data was transformed into interval data using MSI method (Method of Successive Intervals).

\section{Result and Disscussion}

a. The dynamics of extension institutions at the subdistrict level as a node of activity to attract young agricultural actors

Extension institutions experiences ups and downs because of the constantly changing regulations. The dynamics of this change also indirectly affect the efforts to renew the generation of farmers which tend to be slow. The results of descriptive analysis is presented in Table 1.

Table 1. Category of descriptive analysis results on Extention Institutional

\begin{tabular}{|c|c|c|c|}
\hline \multirow{2}{*}{ Institutional Characteristic } & \multirow{2}{*}{ Category } & \multicolumn{2}{|c|}{ Score } \\
\hline & & Total (Person) & $\%$ \\
\hline \multirow[t]{5}{*}{ Leadership } & Very Low $(\leq 25)$ & 1 & 0.87 \\
\hline & Low $(26-50)$ & 33 & 28.70 \\
\hline & Moderate $(51-75)$ & 74 & 64.35 \\
\hline & $\operatorname{High}(76-100)$ & 7 & 6.09 \\
\hline & Average & $59,2(\mathrm{Moc}$ & \\
\hline \multirow[t]{5}{*}{ Score and Purpose } & Very Low $(\leq 25)$ & 7 & 6.09 \\
\hline & Low $(26-50)$ & 28 & 24.35 \\
\hline & Moderate $(51-75)$ & 61 & 53.04 \\
\hline & High $(76-100)$ & 19 & 16.52 \\
\hline & Average & $56,2(\mathrm{Moc}$ & \\
\hline \multirow[t]{5}{*}{ Program } & Very Low $(\leq 25)$ & 2 & 1.74 \\
\hline & Low $(26-50)$ & 22 & 19.13 \\
\hline & Moderate $(51-75)$ & 83 & 72.17 \\
\hline & High $(76-100)$ & 8 & 6.96 \\
\hline & Average & 58,5 (Moc & \\
\hline Source & Very Low $(\leq 25)$ & 2 & 1.74 \\
\hline
\end{tabular}


Institutional Characteristic

\begin{tabular}{|c|c|c|}
\hline \multirow{2}{*}{ Category } & \multicolumn{2}{|c|}{ Score } \\
\hline & Total (Person) & $\%$ \\
\hline Low $(26-50)$ & 51 & 44.35 \\
\hline Moderate $(51-75)$ & 59 & 51.30 \\
\hline High (76 - 100) & 3 & 2.61 \\
\hline Average & $54,1(\mathrm{Moc}$ & \\
\hline
\end{tabular}

Research conducted by Pradiana (2016) showed that the existence value of extension institutions in Sukabumi is considered to be good. However, it turns out that in this study all aspects that characterize the extention institutional belonged to the medium category. This is due to a change in the nomenclature of the extension institutions and structural arrangements that occurred at the end of 2016. As a result, extension institutions became part of technical institutions which tended to local government project activities.

The results of observations showed that the joining of extension institutions and the technical service have positive and negative effects. The positive effect brought was coordination between agricultural extension agents as implementers is relatively better with one direction (instruction) because it cuts bureaucracy pathway during the presence of extension institutions becomes its own sectoral ego. While the negative effect brought was the extension activities are more likely to be not a priority to increase farmers' capacity but rather to carry out official activities. Although these conditions occured, it is expected that whatever happens with the current extension institution it won't effect its function in remaining as the a platform to strengthen our farmers and provide a special attraction for young farmers to take part further in the agricultural sector.

The change in nomenclature is not the first thing that happened, according to the historical record of the condition that has happened several times. In general, extension institutions in Indonesia since Pelita I until now have experienced some changes. First, in 1970-1990, where extension institutional was part of the Mass Guidance (BIMAS) program which was responsible to increase basic commodities to meet maximum production targets. Second, in 1991 the extension agency was re-set up, so that the management of agricultural extension institutions that were originally uner BIMAS were handed over to the technical offices of the agricultural sphere. This period was marked by the emergence of Agricultural Extension Center (Balai Penyuluhan Pertanian/BPP) and Agriculture Extenssion Worker (Penyuluh Pertanian Lapangan/PPL) Food Plants, BPP Plantation, BPP Fisheries, BPP Animal Husbandry. PPL is monovalent. Third, in 1996-2000, the extension institutions at the district/city level were united in a new platform with the Nomenclature of Agricultural Extension Information Center (BIPP) and at the subdistrict level the BPP was re-functioned as the home base of all Agricultural Extension Agents working in the subdistrict.

In the first to third institutional model, the determination and management of extension is carried out by a centralized system. Fourth, in 2001-2005, extension institutional was handed over to the regional government. This era was the beginning of the implementation of a decentralization of extension programs. However, many areas had not been ready which resulted in "comma". Fifth, in 2006-present revitalization of agricultural extension carried out in district and subdistrict extension institutions were revived as outlined in Law No.16 of 2006 regarding Agricultural, Fisheries and Maritime Extension Systems (SP3K), institutions under District Extension Agency (BAPELLUH) and in the BPP subdistrict. This regulation is strengthen by the Minister of Agriculture's Letter No.157, which states that deconcentration funds from the Center will only be given to districts/cities that have established an 
Agricultural Extension Institution. Agricultural extension institution is one of the organizations organized in the agriculture department. The main function of agricultural extension institutions is as a forum and organization for developing agricultural human resources and conducting extension.

b. Factors influencing the capacity of subdistrict level extension institutions to support young agricultural regeneration programs

Various changes experienced by farmers have urged extension institutions to continue to improve. Not only limited to revitalization in the human resource sector which must follow the globalization of information, but also adjust to the new competitive climate. Extension institutional according to Van den ban and Hawkins (1998) should change its structure and culture in order to adapt to massive changing era. Thus, extension institutions will be able to adapt to face challenge and meet the needs of farmers as a client.

Observation in the field showed that the lack capacity of extension institutional result in the slow learning process of farmers and lack of proper guidance for young farmers provided by agricultural extension agents. Based on this fact, the following results of the analysis of factors influencing the institutional capacity to develop young farmers shown in Table 2.

Tabel 2. The results of the statistical analysis of factors influencing the institutional capacity to develop young farmers

\begin{tabular}{cccc}
\hline Component & Score & .p-value & Description \\
\hline R square & 0.228 & $22,8 \%$ \\
\hline Path coefficient of $\mathrm{X}_{1}$ and $\mathrm{Y}_{1}$ & 0.230 & $0.025^{*}$ & Significant \\
\hline Path coeeficient of $\mathrm{X}_{2}$ and $\mathrm{Y}_{1}$ & 0.272 & $0.056^{*}$ & Significant \\
\hline & \multicolumn{3}{c}{ Description : } \\
& $\mathrm{X}_{1}:$ Institutional Characteristic \\
& $\mathrm{X}_{2}$ : Institutional Support \\
& $\mathrm{Y}_{1}:$ Institutional Capacity &
\end{tabular}

Table 2 show that Model $\mathrm{Y}_{1}=0.230 \mathrm{X}_{1}+0.272 \mathrm{X}_{2}+\varepsilon_{1}$ is significant because the $\mathrm{p}$-value is smaller than $\alpha$ which means that the hypothesis regarding institutional characteristics and institutional support has simultaneously significant effect on the institutional capacity in providing guidance to young farmers proven. It can be concluded that institutional capacity of extension can be one of the nodes in mobilizing and fostering young farmers if supported by other factors such as leadership, have detailed program, have competent agents and supported with adequate infrastructure.

The results of this study reinforce the research results of Susmiyati et. al. (2010) which stated that in order to create creative and innovative extension institutions, agricultural apparatuses that are strong, professional, independent, innovative, creative and have a global vision are needed, hence that extension agents can be facilitators, motivators, and regulators. Thus, it can create changes for farmers and regenerate new generation as well.

The results of this study implicated the importance of strengthening institutional support to increase the capacity of extension institutions. Anwarudin and Haryanto (2018) recommended that extension agencies to educate self-help extension agents. Self-help extension agents have proven to be a successful example for young farmers. This can encourage young people to become entrepreneurs in agriculture. Harniati and Anwarudin (2018) reported that young people who become entrepreneurs in agriculture have an interest and their actions in agriculture are better than young farmers in general. 
The next institutional support can be done by prioritizing the participation of all human resources related to the extension agency. Maryani et al. (2017), Anwarudin (2017) and Liani et al. (2018) emphasized that participation has been proven to strengthen institutions. Anwarudin and Maryani (2017) and Putri et al. (2019) added that participation includes participation in planning, implementation and evaluation. Anwarudin and Dayat (2019) reported that participation is a determining factor in the sustainability of agricultural businesses. Thus, in order for the capacity of extension institutions and the efforts of young farmers to be sustainable, it is necessary for the participation of all relevant parties.

Next to see how great the influence of institutional characteristics, institutional support and institutional capacity for young farmers are presented in Table 3.

Table 3. Results of Analysis of Institutional Characteristics Pathway $\left(\mathbf{X}_{1}\right)$, Institutional Support $\left(\mathbf{X}_{2}\right)$ and Institutional Capacity $\left(\mathbf{Y}_{1}\right)$ on the Changes of Young Farmers Behavior $\left(\mathbf{Y}_{2}\right)$

\begin{tabular}{lccc}
\hline \multicolumn{1}{c}{ Component } & Score & .p-value & Description \\
\hline $\mathrm{R}$ square & 0.744 & - & $74,4 \%$ \\
\hline Path coefficient of $\mathrm{X}_{1}$ and $\mathrm{Y}_{2}$ & 0.457 & $0.001^{* *}$ & Significant \\
\hline Path coefficient of $\mathrm{X}_{2}$ and $\mathrm{Y}_{2}$ & 0.181 & $0.031^{*}$ & Significant \\
\hline Path coefficient of $\mathrm{Y}_{1}$ and $\mathrm{Y}_{2}$ & 0.262 & $0.002^{* *}$ & Significant \\
\hline
\end{tabular}

The results of Table 3 show that Model $\mathrm{Y}_{2}=0.457 \mathrm{X}_{1}+0.181 \mathrm{X}_{2}+0.262 \mathrm{Y}_{1}+\varepsilon_{2}$ is significant. These results indicate the strengths of each institutional characteristics, institutional support and extension institution capacity have direct impact on changes in young farmer behavior in managing their farming. This result confirms that young farmer behavior can be built to its prime condition if the extension institution at the district and subdistrict level has synergy with a variety of names and technical functions of the institutions which oversee extension activities. However, the main requirements such as leadership, extension infrastructure, detailed programs and competent extension agents must be met first. The direct effect of each variable on changes in young farmer behavior is illustrated in Figure 1. Based on Figure 1, then determination of the effect of each variable on the change in young farmer behavior can be seen in Table 4.

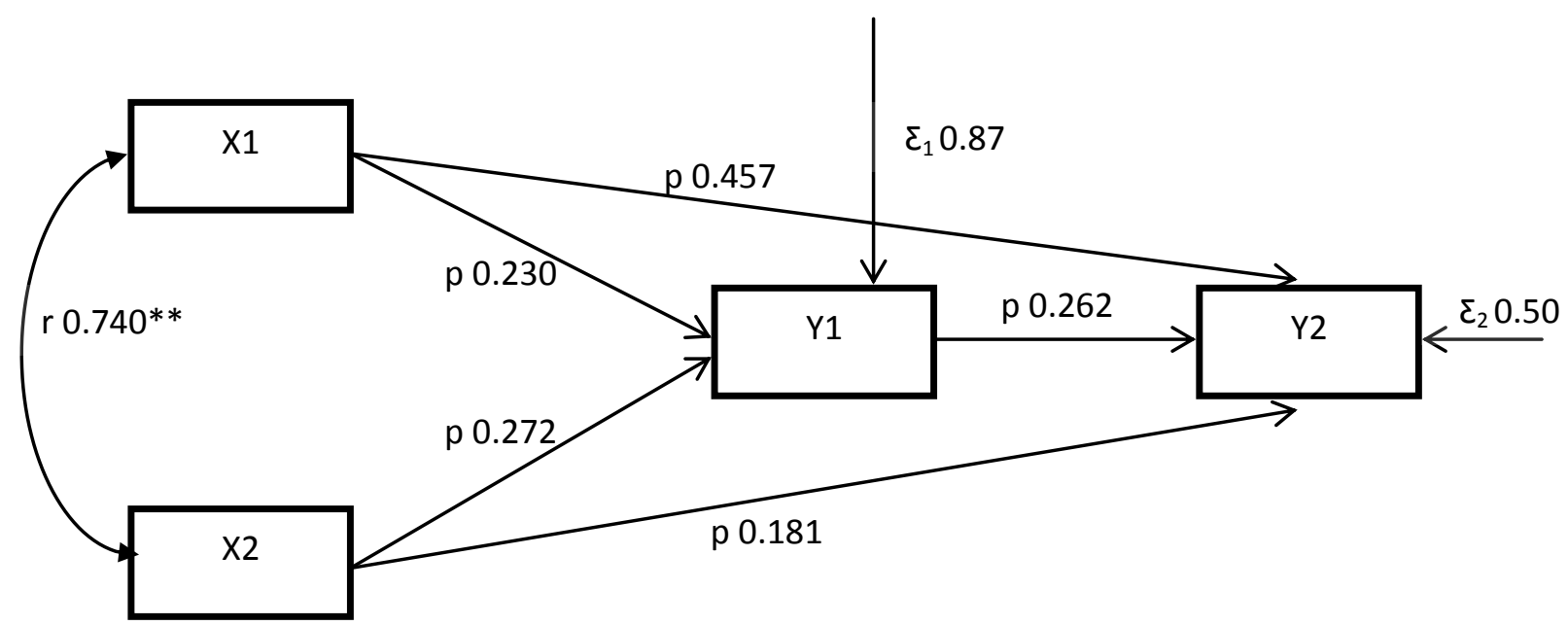

Figure 1. Path diagram of statistic analysis result 
Table 4. The number of direct and indirect effects of each variable

\begin{tabular}{cccc}
\hline Component & Direct effect & Indirect effect & Total effect \\
\hline Effect of $\mathrm{X}_{1}$ to $\mathrm{Y}_{2}$ & 0.457 & Through $\mathrm{Y}_{1}$ & 0.947 \\
& & $0.230+0.260=$ & 0.490 \\
\hline Effect $\mathrm{X}_{2}$ to $\mathrm{Y}_{2}$ & 0.181 & Through $\mathrm{Y}_{1}$ & 0.671 \\
& & $0.230+0.260=$ & 0.490 \\
\hline Effect $\mathrm{Y}_{1}$ to $\mathrm{Y}_{2}$ & & - & 0.260 \\
\hline
\end{tabular}

Overall the effect of each independent variable was above 50\%, thus the path analysis model that has been tested previously can be used as a formulation model to develop appropriate strategies in developing young farmers' behavior through the role of extension institution at the district level which is synergized with implementation at the subdistrict level. Thus, the results indicated that the regeneration of farmers through improving young farmer behavior can be conducted by increasing the capacity, strengthening and character of extension institutions. The results support the research of Wardani and Anwarudin (2018), Anwarudin and Haryanto (2018), Harniati and Anwarudin (2018), Anwarudin et al. (2018), Nazarudin and Anwarudin (2019).

c. Extension institutional strategies in subdistrict level to support young agricultural regeneration programs

One of the fundamental efforts to avoid the "nightmare" of agricultural development is to develop institutional building. Institution is set of rules as the product of values which expected to continue to evolve and become part of culture. This is a prerequisite for the necessary conditions to be "key" for developing competitive, strong and fair agribusiness s.

According to Bestina (2005), Marius (2007), Marliati et al. (2008), Indraningsih et al. (2011), Anantanyu (2011), and Indraningsih et al. (2013), there are several things that should be done immediately so that the revitalization of extension instititution can proceed, namely:

1. There is a leader who is able to formulate the program and policy direction of the institution. A leader must be able to create cooperation between members, create a conducive working climate, and divides tasks and roles of each member clearly.

2. The specification of values, objectives, and operational methods used as a reference in acting by its members. An institution must have a clear purpose and in accordance with the needs of members.

3. The existence of a detailed and structured program, highliting to certain actions related to the implementation of the functions and services that are the output of the institution. Extension institutions are also expected to make definitive guidelines in the preparation of extension work plans that are oriented to the interests of farmers.

4. The availability of quality resources, be it human, physical, technological, and capital resources. Extension institutions are required to be able to obtain, manage, maintain, and mobilize the resources they own. This can be supported by increasing training activities for the development of extension agents.

5. Extension institutions must provide extension agents with knowledge and abilities related to off-farm activities because so far the extension agents only know about on-farm activities. The expertise of extension agents must be improved to meet the needs of diverse farmers. In this way, there will be appreciation and respect from the community for the said agents and public trust will reappear because it places the agents as an opened minded figure who can accept ideas and always interacts with farmers. 
6. The extension institutions should change its agent paradigm to become a consultant by involving the extension agents in developing the program. Thus, extension agents will feel required to be a specialist who will be able to identify and analyze farmers' needs and provide satisfactory services for farmers.

7. Extension institutions in conducting extension activities need to pay attention to the material and extension programs, supporting infrastructure, extension and intensive factors of extension agents, and community involvement.

Based on the path analysis results in the previous discussion and the results of the study as described above, the strategies that can be used to change the behavior of young farmers to remain committed in developing the agricultural sector, especially those in Sukabumi Regency with the existing institutional conditions are:

1. Strengthening the extension institutional characteristics that is integrated with the technical service that is placing field leaders who have adequate knowledge, equipping them with programs that meet the needs of young farmers, maintaining values and goals to support farmers to achieve better living standard and increase resource capacity (agricultural extension agents) as the frontline of technology transfer reformer.

2. Increase institutional management support through the provision of extension infrastructure and develop standard operating procedures (SOP) as a guidance to measurable work outcomes.

3. Creating programs that provide added value to young farmers and are different from prior programs means trying to meet the needs of young farmers.

\section{Conclussion}

All aspects that characterize the extension institutional belonged moderate category. This means that the dynamics of extension institutions have a high level of dynamism as the results of previous studies indicated that several aspects of extension institution characteristics belonged to high category. Characteristics of extension institutions, simultaneously supporting extension institutions have a direct effect on institutional capacity of extension institution and the changes in young farmer behavior. Strategies that can be formulated to change young farmer behavior are to strengthen the characteristics of extension institutions which integrated with technical agencies, increase institutional management support through the provision of extension infrastructure and develop operational standard procedures, as well as create programs with added value for young farmers.

\section{References}

Anantayu, S. (2011). Kelembagaan petani: peran dan strategi pengembangan kapasitasnya. Jurnal SEPA, 7 (2), 102-109.

Anwarudin, O. (2017). Faktor penentu partisipasi petani pada program upaya khusus padi di Kabupaten Manokwari, Papua Barat. Jurnal Penyuluhan Pertanian, 12 (1), 67-79. 
Anwarudin, O., \& Dayat, D. (2019). The effect of farmer participation in agricultural extension on agribusiness sustainability in Bogor, Indonesia. International Journal of Multicultural and Multireligious Understanding (IJMMU), 6 (3), 1061-1072.

Anwarudin, O., \& Haryanto Y. (2018). The role of farmer-to-farmer extension as a motivator for the agriculture young generation. International Journal of Social Science and Economic Research (IJSSER), 3 (1), 428-437.

Anwarudin, O., \& Maryani, A. (2017). The effect of institutional strengthening on farmer's participation and self-reliance in Bogor Indonesia. International Journal of Research in Social Sciences (IJRSS), 7 (4), 409-422.

Anwarudin, O., Sumardjo, S., Satria, A., \& Fatchiya, A. (2018). A Review on farmer regeneration and its determining factors in Indonesia. International Journal of Progressive Sciences and Technologi (IJPSAT), 10 (2), 218-230.

[BPS] Badan Pusat Statistik. 2014. Hasil Sensus Pertanian 2013. Jakarta (ID): BPS.

Bestina, Supriyatno, Slamet, H., \& Amiruddin, S. (2005). Kinerja penyuluh pertanian dalam pengembangan agribisnis nenas di Kecamatan Tambang, Kabupaten Kampar. Jurnal Pengkajian dan Pengembangan Teknologi Pertanian, 8 (2), 218-231.

Liani, F., Sulistyowati, D., \& Anwarudin, O. (2018). Perspektif gender dalam partisipasi petani pada Kawasan Rumah Pangan Lestari (KRPL) tanaman sayuran di Kecamatan Kersamanah Kabupaten Garut Provinsi Jawa Barat. Jurnal Penyuluhan Pertanian, 13 (1), 21-32.

Harniati, H., \& Anwarudin, O. (2018). The interest and action of young agricultural entrepreneur on agribusiness in Cianjur Regency, West Java. Jurnal Penyuluhan, 14 (2), 189-198.

Indraningsih, K. S., Pranadji, T., Budhi, G. S., Sunarsih, Hastuti, E.L., Suradisastra, K., \& Suhaeti, R.N. (2011). Revitalisasi sistem penyuluhan untuk mendukung daya saing industri pertanian perdesaan. Pusat Sosial Ekomoni dan Kebijakan Pertanian. Bogor.

Indraningsih, K.S., Pranadji, T., \& Sunarsih. (2013). Revitalisasi sistem penyuluhan pertanian dalam perspektif membangun industrialisasi pertanian perdesaan. Jurnal Forum Penelitian Agro Ekonomi, $31(2), 89-110$.

Koentjaraningrat. (1997). Kebudayaan, mentalitas dan pembangunan. Jakarta (ID): PT. Gramedia Pustaka Utama.

Marius, Ardu, J., Sumardjo, S., Slamet, M., \& Asngari, P. S. (2007). Pengaruh faktor internal dan eksternal penyuluh terhadap kompetensi penyuluh di Nusa Tenggara Timur. Jurnal Penyuluhan, 3 (2), 78-89.

Marliati, Sumardjo, S., Asngari, P. S., Tjitropranoto, P., \& Saefuddin, A. (2008). Faktor-faktor penentu peningkatan kinerja penyuluh pertanian dalam memberdayakan petani (kasus di Kabupaten Kampar Provinsi Riau). Jurnal Penyuluhan, 4 (2), 92-99.

Maryani, A., Haryanto, Y., \& Anwarudin, O. (2017). Strategy of agricultural extension to improve participation of the farmers in special effort in increasing rice production. International Journal of Sciences: Basic and Applied Research (IJSBAR), 36 (4), 163-174. 
Nazaruddin, N., \& Anwarudin, O. (2019). Pengaruh penguatan kelompok tani terhadap partisipasi dan motivasi pemuda tani pada usaha pertanian di Leuwiliang, Bogor. Jurnal Agribisnis Terpadu, 12 (1), 1-14.

Pradiana, W. (2016). Peran penyuluh pertanian dan kapasitas kelembagaannya di tingkat kecamatan dalam mendukung program peningkatan produksi padi jagung dan kedelai di Kabupaten Sukabumi. [Laporan Penelitian]. Bogor (ID): STPP Bogor.

Putri, C. A., Anwarudin, O., \& Sulistyowati, D. (2019). Partisipasi petani dalam kegiatan penyuluhan dan adopsi pemupukan padi sawah di Kecamatan Kersamanah Kabupaten Garut. Jurnal Agribisnis Terpadu, 12 (1), 103-119.

Susmiyati, Maryani, A., \& Kusnadi, D. (2010). Kinerja penyuluhan pertanian PNS dalam melaksanakan tupoksi di Kabupaten Bogor (Kasus di BP3K Cibungbulang). Jurnal Penyuluhan Pertanian, 5 (1), 87-103.

Tony, N. F. \& Utomo, B. S. (2004). Pengembangan Kelembagaan dan Modal Sosial. Modul Kuliah Magister Profesional Pengembanan Masyarakat Departemen Ilmu-Ilmu Sosial Ekonomi Fakultas Pertanian Institut Pertanian Bogor.

Van Den Ban, A.W., \& Hawkins, H. S. (1999). Penyuluhan Pertanian. Yogyakarta (ID): Kanisius.

Wardani, W., \& Anwarudin, O. (2018). Peran penyuluh terhadap penguatan kelompok tani dan regenerasi petani di Kabupaten Bogor, Jawa Barat. Jurnal Tabaro Agriculture Science, 2 (1), 191-200.

\section{Copyrights}

Copyright for this article is retained by the author(s), with first publication rights granted to the journal.

This is an open-access article distributed under the terms and conditions of the Creative Commons Attribution license (http://creativecommons.org/licenses/by/4.0/). 